THE ROLE OF TRADITIONAL AUTHORITIES IN DEVELOPING CUSTOMARY LAWS IN ACCORDANCE WITH THE CONSTITUTION: SHILUBANA AND OTHERS V NWAMITWA 2008 (9) BCLR 914 (CC)

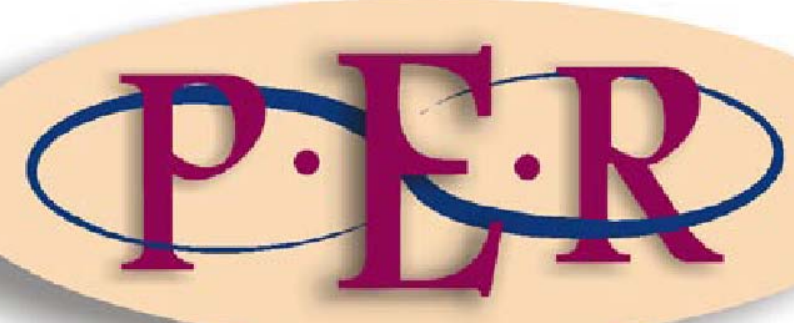

2009 VOLUME 12 No 3 


\section{THE ROLE OF TRADITIONAL AUTHORITIES IN DEVELOPING CUSTOMARY LAWS IN ACCORDANCE WITH THE CONSTITUTION: SHILUBANA AND OTHERS V NWAMITWA 2008 (9) BCLR 914 (CC)}

\section{B Mmusinyane*}

\section{Introduction}

South Africa's constitutional dispensation is based on the premise that all existing laws are subject to the Constitution of the Republic of South Africa 1996 (the Constitution), including African customary law, and that all laws are limited only by the Constitution. ${ }^{1}$ South African customary law is a body of law by which millions of South Africans regulate their lives in a multicultural society. ${ }^{2}$ It existed long before the adoption of the Constitution which, among other things, aims at harmonising the different cultural practices that exist in the country. It is apparent that some traditional cultural practices that still exist are in conflict with the Constitution but, until they are challenged before a court of law, they will remain enforceable in our communities.

In other words, even though the Constitution is in force, there are many unresolved theoretical and practical problems arising from the application of customary law within the constitutional framework. ${ }^{3}$ For example, many customary systems of succession are guided by the principle of male primogeniture: a deceased's heir is his eldest son, failing which, the eldest son's oldest male descendant is his heir. ${ }^{4}$ In most cultural traditions women are ineligible to be traditional leaders of their tribes. When the traditional leader has only daughters, the throne automatically passes to his brother or oldest living male heir. It is apparent that, if male children are linked through their father to

* $\quad$ LLB (U) Vista, LLM (UP), Lecturer: Department of Private Law, School of Law, UNISA.

1 Rautenbach 2003 Stell LR 109 and 113.

Schoeman-Malan 2007 PER 1.

Himonga and Bosch 2000 SALJ 317-318.

SALC 1998 www.saflii.org/. Bennett Customary law 335. Rautenbach and Du Plessis 2004 SAJHR 1. 
the royal lineage, their inheritance of the traditional chieftaincy is guaranteed irrespective of their seniority or age. This custom, which entails that traditional chieftaincy is retained only in the male line, is in most instances enforced by traditional authorities. The traditional authorities can be seen as communal structures that are capable of either perpetuating the primogeniture principle or developing community customs to bring them in line with the aspirations of the Constitution. It may be asked to what extent traditional authorities are capable of doing the latter. This case note aims at analysing the traditional authority's role in the development of customary practices in line with the Constitution, particularly with regard to the advancement of the right of women to inherit traditional chieftaincy thrones. To date, the emphasis is still mainly on the advancement of women's and children's rights in general, a process that seems to be advancing too slowly, despite being rooted in constitutionally protected rights.

The decision of the Shilubana $v$ Nwamitwa $^{5}$ is subsequently discussed. The case concerns an application to the Constitutional Court for a leave to appeal against a decision of the Supreme Court of Appeal ${ }^{6}$ substantially confirming a decision of the Pretoria High Court ${ }^{7}$ that prevented a woman from being a Hosi of her own community.

\section{Facts}

The facts of the case were as follows: The principle of primogeniture governed the succession to the traditional chieftaincy of the Valoyi community for five generations. ${ }^{8}$ On the death of the Hosi (traditional leader), Fofoza Nwamitwa, in 1968 , the traditional chieftaincy lineage of the Valoyi community was disrupted. Since Hosi Fofoza's eldest child was a daughter and he did not have a male heir, his brother Richard Nwamitwa succeeded him as Hosi of the Valoyi. Hosi

5 Shilubana v Nwamitwa 2008 (9) BCLR 914 (CC) (hereafter the Shilubana case).

6 Shilubana v Nwamitwa (Commission for Gender Equality as Amicus Curiae) 2007 (2) SA 432 (SCA) (hereafter Shilubana $v$ Nwamitwa).

$7 \quad$ Nwamitwa v Phillia 2005 (3) SA 536 (T) (hereafter the Nwamitwa case).

8 Nwamitwa case 540F (n 11). 
Richard succeeded to the throne despite the fact that Hosi Fofoza's eldest daughter (Ms Shilubana) was old enough to be given the throne. ${ }^{9}$ In 1996 the Valoyi Royal Council unanimously resolved to restore the chieftainship to Hosi Fofoza's eldest daughter. The resolution noted: ${ }^{10}$

[T]hough in the past it was not permissible by the Valoyis that a female child be heir, in terms of democracy and the new Republic of South Africa Constitution it is now permissible that a female child be heir since she is also equal to a male child. The matter of chieftainship and regency would be conducted according to the Constitution of the Republic of South Africa.

However, Ms Shilubana did not want to replace Hosi Richard at that stage, and he continued to rule. In 1997 Hosi Richard endorsed a resolution appointing Ms Shilubana as Hosi but later, in 2001, he withdrew his support. After the death of Hosi Richard in 2001, the chieftainship of the Valoyi community, the royal family, tribal council, local government representatives, civic structures and stakeholders of various organisations again proclaimed Ms Shilubana as the Hosi. ${ }^{11}$ Hosi Richard's eldest son, Sidwell Nwamitwa, obtained a court interdict against the inauguration ceremony of Hosi Shilubana on the grounds that he was entitled to succeed to the traditional chieftaincy of the Valoyi as an heir to the late Hosi Richard. He obtained a further court order that the third to sixth applicants (third applicant: District Control Officer, fourth applicant: the Premier, Limpopo Province, fifth applicant: MEC for Local Government and Housing, Limpopo, sixth applicant: National House of Traditional Leaders) should withdraw the letters of appointment issued to Ms Shilubana and should instead issue letters of appointment to him. ${ }^{12}$

The High Court and the Supreme Court of Appeal decisions respectively found that prior to the interim Constitution, ${ }^{13}$ in terms of the Valoyi cultural practices from 24 October 1968 and at least prior to 1994, women could not be appointed

$9 \quad$ Nwamitwa case 540F par 3 (n 11).

10 Nwamitwa case 540F par 4 (n 11).

11 Nwamitwa case 540F par 5-6 (n 11).

12 Nwamitwa case 540F par 6-7(n 11).

13 Constitution of the Republic of South Africa Act 200 of 1993 (Interim Constitution). 
as a Hosi. ${ }^{14}$ Therefore, the SCA agreed with the high court on the following grounds: $^{15}$

(a) That its finding was not gender-based since the facts of the case "do not bring [it] to the gender equality claim which the [applicants seek] to vindicate".

(b) That the official appointment of Ms Shilubana was not in accordance with the customs and traditions of the Valoyi, and that these customs were not constitutionally problematic.

Therefore, Ms Shilubana took the matter to the Constitutional Court on the grounds that she had been prevented from being a Hosi by virtue of her gender. The Constitutional Court set aside the decisions of the Supreme Court of Appeal with the under-mentioned judgment.

\section{The decision of the Constitutional Court}

The Constitutional Court had to clarify the issues described below for the consistent development and application of customary law by a consideration of the following: (1) whether or not a traditional authority has a duty to develop its customs and traditions in contemplation of promoting gender equality in the succession of chieftainship, in accordance with the Constitution, even if this discrimination occurred prior to the coming into operation of the Constitution; and (2) the way courts of law are to apply customary law as required by the Constitution, while acknowledging and preserving the institution and role of chieftainship and the functioning of a traditional authority that observes customary law.

The Constitutional Court noted section 211 of the Constitution, that is, that the institution, status and role of chieftainship are recognised subject to the 
Constitution. Therefore observance of customary law by traditional authorities must be in accordance with the applicable legislation and customs, including amendments to or repeal of that legislation and those customs. Thus it is the duty of the court to apply customary law where it is applicable, subject to the Constitution and relevant legislation. ${ }^{16}$ The norms of customary law are informed by factors such as the traditions of the community concerned as guided by a consideration of the past practices of the community. ${ }^{17}$ The court found that the development of customary law would imply some departure from past practices which seem to constitute a threat. A threat to the recognition of the development of customary law occurs when a rule requires an absolute consistency with past practice before a court will recognise the existence of a customary norm. This would result in the courts' applying laws which communities themselves no longer follow, and would stifle the recognition of new rules adopted by the communities in response to the changing face of South African society. This route would be in conflict with the aspirations of the Constitution and thus unacceptable to society at large.

Therefore the development of customary law must be guided by the contemporary practice of the community in question. ${ }^{18}$ The court acknowledged that past practices should not be interpreted as being irrelevant in today's society, since such practices and traditions may still be of considerable importance in customary law, but should be considered together with other important factors. The court further made it clear that the time when customary law had to be proved as foreign law in South Africa is a thing of the past. ${ }^{19}$ In consequence, where a norm emanates from a tradition, with no indication that a contemporary development has occurred or is occurring, past practice will be sufficient to establish a rule. However, in instances where the contemporary practice of the community suggests that change has occurred, past practice

16 Shilubana case par 42 ( $\mathrm{n}$ 9).

17 Shilubana case par $44(\mathrm{n} 9)$.

18 Shilubana case par 55 (n 9), Van Breda v Jacobs 1921 AD 330 (hereafter Van Breda case).

19 Mabuza v Mbatha 2003 (4) SA 218 (C), 2003 (7) BCLR 743 (C) par 30 (hereafter Mabuza case). 
alone is not enough and does not establish a right with certainty. ${ }^{20}$ Past practice will also not be decisive where the Constitution requires the development of the customary law in line with constitutional values. ${ }^{21}$

It is, furthermore, the very same community that observes customary law that must develop it, and this communal decision must be respected in accordance with section 211 of the Constitution. Therefore, the free development by communities of their own laws to meet the needs of a rapidly changing society should be encouraged, respected and facilitated. ${ }^{22}$ The Constitution had done away with the hierarchy of laws in which parliamentary statutes and common law were preferred over customary law. 'Living' customary law was not always easy to establish and it might sometimes not be possible to determine a new position with clarity. The court encouraged the parties to assist it in resolving their disputes by placing credible evidence of the present practice in their communities before it. The duty of the court, in those instances, would be to examine the law in the context of a community and to acknowledge developments if they had occurred. ${ }^{23}$ The court found that the need for flexibility and the imperative to facilitate development must be balanced against the value of legal certainty, respect for vested rights and the protection of constitutional rights. In the Bhe case, the Constitutional Court found that the protection of women and children would be achieved by not allowing the development of the customary law of succession in a piecemeal and sometimes slow fashion. ${ }^{24}$ In adjudicating a customary law matter the court must remain mindful of its obligations under section 39(2) of the Constitution to balance the development of customary law by the communities with the jurisdiction of the courts. $^{25}$ In addition, the Constitutional Court held in

20 Mabuza case par 44-49 (as above).

21 Shilubana case par 56 (n 9).

22 Shilubana case par 45 (n 9).

23 Shilubana case par 46 (n 9); Bhe v Magistrate, Khayelitsha (Commission for Gender Equality as Amicus Curiae); Shibi v Sithole; South African Human Rights Commission v President of the Republic of South Africa 2004 ZACC 17; 2005 (1) SA 580 (CC); 2005 (1) BCLR 1 (CC) (hereafter the Bhe case) par 86,107 and par 152-154.

25 Shilubana case par 48 (n 9). 
Carmichele $v$ Minister of Safety and Security ${ }^{26}$ that section 39(2) imposes an obligation on courts to consider whether or not there is a need to develop the common law to bring it into line with the Constitution and, if so, to develop it, as was the case with customary law. ${ }^{27}$ The court would, however, respect and enforce any development that happened within the community to the extent that such development was in line with the protection of rights.

In addition, the imperative of section 39(2) must be acted on when necessary and deference should be paid to the development by a customary community of its own laws and customs where this is possible and consistent with the continuing effective operation of the law. ${ }^{28}$ In determining Sidwell Nwamitwa's claim to the traditional chieftaincy, the Constitutional Court held that the past practice of the Valoyi was important but not decisive in determining whether or not Mr Nwamitwa had the right he claimed. ${ }^{29}$ The Valoyi authorities intended to bring an important aspect of their customs and traditions into line with the values and rights of the Constitution. Several provisions of the Constitution require the application of the common law and customary law, as well as the practice of culture or religion, to comply with the Constitution. ${ }^{30}$ If traditional authorities purported to apply customary law subject to the Constitution, ${ }^{31}$ it must next be asked whether or not they had the authority to act as they did. The Constitutional Court found that there was no evidence to permit it to rule on traditional authorities, as they had a broad discretion in appointing a traditional leader and were not bound simply to appoint the heir by birth. Therefore it had no basis on which to overturn the High Court's finding that, in terms of the existing customary law, the role of the royal family is more than formal only where there is no candidate for the chieftainship, or where the candidate is not suitable, which was not alleged to be the case in the matter under consideration. Intervening) 2001 ZACC 22; 2001 (4) SA 938 (CC); 2001 (10) BCLR 995 (CC) par 34-36 (hereafter Carmichele case).

27 Bhe case par 44, 48 and 215 (n 28).

28 Shilubana case par 49 (n 9).

29 Shilubana case par 57 (n 9).

30 Refer in this regard to sections 1(c), 2, 30 and 31 of the Constitution.

31 Shilubana case par 68 (n 9). 
However, even if the High Court were correct on that point, it had to be true that the traditional authorities had the power to act as they did for the reasons that follow. ${ }^{32}$ It was noted that the traditional authority was the highest decisionmaking structure within the traditional community on matters of succession. If the authorities had only the narrow discretion the High Court found them to have, it followed that no other body in the community had more power in that regard. This would therefore mean that nobody in the customary community would have the power to make constitutionally driven changes in chieftainship. This result could be seen if one considered what would have happened, in the narrow view, if the traditional authorities in the present case had sought simply to install a woman as Hosi. Even if she were the eldest child of the previous traditional leader, it would follow on the narrow view that the traditional authorities would have no power to appoint her unless there was no other heir or the male heir was unfit to rule. It would be necessary, according to this view, to approach the courts before a woman could be installed as a Hosi. ${ }^{33}$ The court emphasised the need to empower communities to bring their customs in line with the norms and values of the Constitution. Any other result would be contrary to section 211(2) and would be disrespectful of the close bonds between a customary community, its leaders and its laws. ${ }^{34}$ If the traditional authority had only those powers accorded it by the narrow view, it would be contrary to the Constitution and frustrate the achievement of the values in the Bill of Rights. The court's power in section 39(2) of the Constitution should be exercised judiciously and sensitively, in an incremental fashion, ${ }^{35}$ and in a manner that would empower the community itself to continue the development. ${ }^{36}$

As the Supreme Court of Canada ${ }^{37}$ had held in relation to the common law,

32 Shilubana case par 71 ( $\mathrm{n}$ 9).

33 Shilubana case par 72 ( $\mathrm{n}$ 9).

34 Shilubana case par 73 (n 9).

35 Du Plessis v De Klerk 1996 ZACC 10; 1996 (3) SA 850 (CC); 1996 (5) BCLR 658 (CC) par $167 / 174$ and 189 (hereafter Du Plessis case).

36 Shilubana case par 74 (n 9).

$37 R$ v Salituro 19928 CRR (2d) 173 at 189. 
[t]he judiciary should confine itself to those incremental changes which are necessary to keep the common law in step with the dynamic and evolving fabric of our society.

The court found that this statement, in the South African context, should not be seen to detract from the obligation of courts to uphold the new values with which our legal system has been infused ${ }^{38}$ Therefore, the court found that the appointment of Ms Shilubana as a Hosi represented a development of customary law which was an essential step in respecting community-led change parallel with the value of legal certainty and the need to protect rights. ${ }^{39}$ The legal effects of the change - the installation of a particular leader - were clear. Mr Nwamitwa was not a Hosi but had an expectation to be appointed Hosi owing to the 1968 decision and on the basis of past practice. The court found that his expectation could not override the decision of the traditional authorities to adapt their customs in accordance with the values and rights of our democracy as embodied in the Constitution. ${ }^{40}$ The actions of a traditional authority could not be illegitimate just because they involved a departure from past practice. ${ }^{41}$ The Valoyi authorities had chosen to restore the line of Hosi Fofoza going back one generation, although it was true that Ms Shilubana's installation left some questions unanswered relating to how the Valoyi succession would operate in the future. However, customary law was living law and would in future inevitably be interpreted, applied and, when necessary, amended or developed by the community itself or by the courts. This would be done in the light of existing customs and traditions, previous circumstances and practical needs and, of course, the demands of the Constitution as the supreme law.

Although the Valoyi people had moved away from any previously existing rule that a woman could never be appointed as a Hosi, other aspects of the customs and traditions governing chieftainship had not necessarily been affected. For example, the principle that a Hosi is born and not elected indeed 
exists; it was not necessarily changed by this ruling as Ms Shilubana was born as the child of a Hosi. Her birth was crucial to the decision of the royal family. ${ }^{42}$ Furthermore, such additional developments of the law as Ms Shilubana's installation might necessitate were in the first instance a matter for the relevant traditional authorities, acting in accordance with custom, practical needs and the Constitution. It was, however, not these future decisions that were before the Constitutional Court, and nothing further had to be said about them. ${ }^{43}$ The value of recognising the development of its own law by a traditional authority was not in this instance outweighed by factors relating to legal certainty or the protection of rights. The royal family intended to act to affirm the constitutional values in chieftainship in its community. A balancing of the effects of its action revealed no consideration that should prevent the Constitutional Court from recognising its actions as such. ${ }^{44}$ The Constitutional Court found that the conclusions of both the High Court and the Supreme Court of Appeal that the traditional authorities lacked the power to act as they did were incorrect. The court found that the Supreme Court of Appeal erred in its judgment, as its decision was too narrow and tied to the statement that a Hosi is never appointed but born, and unable to countenance that the lineage would change from that of Hosi Richard to that of Hosi Fofoza. Accordingly, Mr Nwamitwa had no vested right to the chieftainship of the Valoyi, but only an expectation to be a Hosi. However, past practice of the Valoyi community was not determinative and did not itself guarantee that Mr Nwamitwa's possible expectation had to be fulfilled. The contemporary practice of the Valoyi reflected a valid legal change, resulting in the succession of Ms Shilubana to the chieftainship. 


\section{$4 \quad$ Evaluation}

\subsection{Appointment of women to traditional chieftaincy thrones}

Both the legislature and the judiciary are mandated to provide remedies in order to correct injustices and promote the values that underlie an open and democratic society, such as equality, human dignity and freedom. ${ }^{45}$ Despite numerous objections to women as leaders in their respective communities, recent trends indicate that the 1996 Constitution is progressively harmonising customary practices with constitutional values in enabling women to occupy traditional chieftaincy thrones. The following examples indicate the changing trends in viewing women as equally capable leaders in their respective communities.

The first example is the succession of the daughter of the late traditional leader Serobatse of the Bafokeng Ba Ga Motlala in Lichtenburg, North-West Province, which was occasioned by the traditional leader not having a male heir. Although she ascended the throne as the daughter of the traditional leader, her descendants are not entitled to the throne because the link with the royal family in her case is through the mother and not the father, as is required by custom. ${ }^{46}$ In Botswana the progressive development of customary law reached a notable milepost when a woman was appointed by the tribal authority as the first traditional leader in her community after both her brother and her father had died. ${ }^{47}$ However, the development of customary law in this regard seems to have been clouded with much controversy prior to the acceptance that women should enjoy the same right as men to rule their communities.

This controversy can be best illustrated by the objections which have been raised since 1999 with regard to the traditional chieftaincy claim by Refilwe Mabalane (Refilwe) of the Baphiring community in the North-West Province on the grounds that she is a woman, despite her being the eldest daughter of her

45 Van Rensburg 2001 Obiter 217.

46 Ntshabele "Reflections".

47 BBC News 2008 news.bbc.co.uk. 
late father. Of six children born into the royal family Refilwe is the eldest child, and her brother is the fifth-born. Refilwe's case is yet to be resolved. On the face of it, Refilwe faces direct discrimination against her as a woman, since the chieftaincy throne has traditionally been exclusively reserved for men. ${ }^{48}$ Nevertheless, the fact that more communities seem to accept women as their leaders reflects the progress of true gender transformation in chieftainship. The Shilubana judgment must be seen as a classic example of the application of customary law by the traditional authority that is in line with the Constitution as well as with principles of public policy and natural justice. ${ }^{49}$ The Shilubana judgement reflects the plight of women under customary law.

\subsection{Exposition of the position of women under customary law}

It needs to be acknowledged that women have been assigned a subservient role by customary practices since time immemorial. Their stigmatisation by their communities has played a critical role in discrimination against their gender for many years, and it has exposed women to various obstacles of a historical and cultural nature to their active and equitable participation in the political and social realms (particularly in denying them access to traditional chieftaincies). This was largely a function of men's traditional roles as breadwinners and defenders of the family against danger. ${ }^{50}$ The traditional chieftaincy, according to the rules of patrilineal succession, was always inherited by the eldest son of the founding father of the land. ${ }^{51}$

Clearly, if they objected to this custom women could have been ostracised for disobeying the dictates of the culture of their community, and thus deemed to be inviting misfortune. Bennett states that women were treated as minors in traditional African society; ${ }^{52}$ while still unmarried, a woman remained under the guardianship of her father or uncle, and after her marriage she was under the

48 Molefe 'Judgment' City Press 11.

49 Van Rensburg (n 45) 219.

50 Mokotjo 2006 www.ufs.ac.za.

51 Bennett (n 4) 120. See also Olivier et al Indigenous law 4-5.

52 Bennett (n 4) 251-252. 
guardianship of her husband. ${ }^{53}$ One exception to this is the custom of the Modjadji community, which dictates that only women may rise to the leadership of their community. From 1854 until 2005 all of the leaders of the Modjadji community have been women. ${ }^{54}$ On the basis of the Shilubana decision, the Modjadji customs can be challenged on the basis of gender discrimination, and there would be no merit in attempts to deny the claims of any rightful male heir on the grounds of his gender. Despite improvements in the protection of women's rights, gender discrimination is still prevalent in South African society. Little has changed in the lives of ordinary women, many of whom are subject to customary law, tradition and other patriarchal social and cultural practices. ${ }^{55}$ Bennett states that, because African culture is steeped in the principle of patriarchy, the gender equality clause threatens a thorough purge of customary law. ${ }^{56}$ One example is the achievement of gender equality in traditional authorities, which is still seen as a challenge. In terms of customary law, with the exception of the Modjadji traditional chieftaincy, women may not hold political office. $^{57}$

Traditional authorities have lobbied in vain to have customary law exempted from the Bill of Rights, ${ }^{58}$ one of their reasons being that they saw the Constitution as a threat to their customary and traditionally accepted views on the position of women in society. However, the drafters of the Constitution declared gender equality as one of the non-negotiable clauses to be included therein. ${ }^{59}$ The adoption of the Constitution was a milestone in ending discrimination and ensuring equality for all, particularly previously disadvantaged groups - women constituting one of the most severely disadvantaged groups. It was found in Egan v Canada ${ }^{60}$ that discrimination can come about as much as an effect of distinctions that are in themselves not intentionally discriminatory as from an overtly discriminatory purpose, and those individuals

53 Ntshabele (n 46).

54 Molefe 'Ruling' City Press 11.

55 Gender Links [no date] www.genderlinks.org.za/.

56 Bennett 1994 SAJHR 122.

57 Molefe 'Ruling clouds' City Press 11.

58 Ntshabele (n 46)

59 Ntshabele (n 46).

60 Egan v Canada (AG) 1995 (2) SCR 513 par 38. 
and groups that are more generally vulnerable in society are also likely to experience the discriminatory effects of such distinctions more severely. The final Constitution can be regarded as a catalyst that aims to ensure the removal of all traces of patriarchy in our society. ${ }^{61}$ It promotes non-discrimination and requires everyone to be treated with equal dignity irrespective of the obedience to traditional cultural values that a certain community may have observed until now. ${ }^{62}$ It should be noted that customary law was designed principally to regulate family relationships. Although most women in contemporary society, through force of circumstances, engage in extra-familial activities, there is no directly relevant rule of customary law to govern this novel situation aside from generally outdated notions that women are subordinate to men. ${ }^{63}$

Albertyn and Goldblatt state that equality, as a value and as a right, is central to the task of transformation. ${ }^{64}$ As a value, equality gives substance to the vision of the Constitution. As a right, it provides the mechanism for achieving substantive equality, thus legally entitling groups and persons to claim the promise of this fundamental value and providing them with the means to achieve it. The Constitution regards everyone as being equal in the eyes of the law, and has entrenched the practical implementation of this equality. This means that no one is perceived as having more rights than others, and that men and women enjoy equal rights regardless of their culture, status and gender. It is the same customary practices that allow women to act as regents in situations where an heir may not be in a position to ascend the throne. Such a practice can be seen in Lichtenburg, in the North-West Province, where the widow of the late traditional leader Seatlholo was appointed to rule the community in an acting capacity on her son's behalf from the time of her husband's death. ${ }^{65}$ Therefore, the permanent appointment of a woman would not come as a surprise to the communities concerned. The debate around the continued existence of many (if not virtually all) customary practices in the

61 Ntshabele (n 46).

62 S 9 of the 1996 Constitution.

63 Bennett (n 4) 127. Heureux-Dube 1997 SAJHR 338.

64 Albertyn and Goldblatt 1998 SAJHR 248.

65 Ntshabele (n 46). 
constitutional dispensation usually manifests as a conflict between the right to gender equality and the right to culture. ${ }^{66}$ As a signatory of the Convention on the Elimination of all Forms of Discrimination against Women (CEDAW), South Africa has an obligation under international law to eradicate all forms of discrimination against women. ${ }^{67}$ In terms of article 2(f), states are called upon to

take all appropriate measures, including legislation, to modify or abolish existing laws, regulations, customs and practices which constitute discrimination against women. ${ }^{68}$

Therefore the advancement of women's rights in South Africa can be seen as a progressively developing process under the guidance of both the Constitution and international law.

The patrilineal way of doing things has been remodelled to accommodate women as leaders of their communities. This accommodation has initiated discussion regarding the role of women in other cultural practices that have been exclusively reserved for males. Such cultural practices include but are not limited to the performance of certain customary rituals that were mainly performed by men, allowing women to now enter previously secluded places such as a cattle kraal to participate in certain rituals. But it remains up to the respective traditional authorities to prescribe from time to time how such cultural practices that conflict with their constitutional rights could be remodelled to include women who are leaders in their communities.

\subsection{The role of traditional authorities in developing customary law}

\subsubsection{Transformation of the traditional leadership}

The transformation of traditional leadership (as defined below) was spearheaded by the enactment of the Traditional Leadership and Governance Framework Act. ${ }^{69}$ This Act aims to transform traditional leadership in line with

66 Pieterse 2000 De Jure 39.

67 CEDAW 2006 www.un.org/womenwatch/daw/cedaw/states.htm.

68 CEDAW (n 67).

69 Traditional Leadership and Governance Framework Act 41 of 2003.

150/161 
the Constitution, at the same time undertaking to restore the integrity and legitimacy of the traditional authority as an institution in accordance with customary laws and practices. ${ }^{70}$ One of its goals is the progressive realisation of gender equality within traditional authorities in a manner that promotes freedom, human dignity, and the achievement of equality and non-sexism. To ensure compliance with these undertakings, the Act determines that at least a third of the members of a traditional council must be women. ${ }^{71}$

Section 3(2) (d) of the Traditional Leadership and Governance Framework Act determines that where it has been proved that an insufficient number of women are available to participate in a traditional council, the Premier concerned may, in accordance with a procedure provided for in the provincial legislation, determine a lower threshold for the particular traditional council than that required by paragraph (b) of the same section. ${ }^{72}$ However, there is a huge disparity between reality and the ideal of what the Act states to be a minimum threshold. As a rule, the members of traditional councils are still predominantly men, who are reluctant to relinquish their customs to accommodate women. The Act envisages that the appointment of traditional leaders should be done with due regard to the observance of the customary laws of the community concerned. ${ }^{73}$ The Act accommodates the role of traditional leaders on all levels of executive government, but it is a role that is more symbolic than substantive. ${ }^{74}$ The ruling on the role of traditional authorities in the Shilubana judgment may have come at a time when it was not expected by most African communities that reserve traditional leadership exclusively for men.

\subsubsection{Defining traditional authority/leadership}

Traditional authority/leadership is defined as an aggregate institution which includes the position of the traditional leader or king, the deputy, the royal family, the secret advisory body, the headmen of small villages, and the

70 Bennett (n 4) 114.

71 S $3(2)(b)$ of the Act ( $n$ 75).

72 S 3(2) (d) of the Traditional Leadership and Governance Framework Act (n 69).

73 Ntshabele (n 46).

74 Ntshabele (n 46). 
traditional council. ${ }^{75}$ Previously traditional authorities were generally viewed as still holding conservative views about the customs and traditions of their communities. ${ }^{76}$ Traditional authorities are perceived to be at the forefront of hindering the development of customary laws in accordance with the applicable constitutional principles. At the same time they are seen as playing a critical role in the day-to-day operation of their communities by ensuring observance of and compliance with the customs of the community by the subjects, as well as disciplining contraventions by members of the community. ${ }^{77}$

It is clear that the exercise of their power must operate within the parameters of the Constitution. Moreover, these authorities must be seen to play an important part in the development of customary law in line with the Constitution. They should monitor whether or not socio-economic and political developments are taking place in their communities. They enjoy a high status and significant support among their people since they are regarded as the custodians of African culture and customary law, and hence they also perform a variety of important executive and judicial functions. ${ }^{78}$ Accordingly, they play a critical role in educating and empowering their community to understand the impact of the Constitution and its relations with their customary laws. As a result they should also be able to develop their customary laws in line with the Constitution without first being forced to do so by the courts.

\subsubsection{Who should develop customary law?}

The Constitutional Court has noted the power of traditional authorities to make constitutionally driven changes to customs and traditions, as failure to do so would frustrate the objectives of the Constitution. Customary law is adaptive by nature and the courts should recognise any changes in customary law, especially where such changes bring the customary law in line with the values and spirit of the Constitution. ${ }^{79}$ Therefore the traditional authorities, not the 
courts, must be responsible for developing customary law in line with the Constitution. ${ }^{80}$ What differentiates this approach from the court-driven one is that customs and traditions that have been developed directly by traditional authorities can be seen to have a sense of belonging to the communities.

Courts are seen as socially distanced from the communities they serve, so their knowledge of customary law is bound to be second-hand. ${ }^{81}$ Unlike ordered dispositions by the courts, traditional authorities regard themselves as being at the forefront of developing their own customs and traditions. In instances of disputes, the duty of the court will be limited to exercising its powers conferred by section $39(2)^{82}$ to determine if the purported development by the traditional authority did promote the spirit, purport and objects of the Bill of Rights. ${ }^{83}$ Section 211(2) of the Constitution ${ }^{84}$ regards traditional authorities as primary agents of development. They are seen as the representatives of the community and as such are entrusted with an important responsibility, namely that of harmonising community customs and traditions with the ethos of the Constitution. ${ }^{85}$ However, traditional authorities should not see themselves as unilateral decision makers. They are still required to consult with their communities about matters that will particularly affect the community's customs and traditions. This is based on the premise that it is the communities at large that will have to conform to the developed traditions and customs. Hence, such traditions and customs cannot be changed without the community's knowledge or consultation. It is important to respect the right of communities that observe a system of customary law to develop their law, particularly if the initiative comes from them. ${ }^{86}$ Only if the community at large fails to develop its customs will evidence have to be placed before the courts of the present practice of that

80 Shilubana case par 68, 72, and 73 (n 1), s 39(2) and 211(2) of the Constitution.

81 SALC 'Harmonisation'.

82 Shilubana case par 74 (n 9).

83 S 39 (2) of the 1996 Constitution.

84 The 1996 Constitution.

85 The 1996 Constitution.

86 Shilubana case par 45 (n 9). 
community. The court will then have to examine the law in the context of the community and acknowledge developments if they have occurred. ${ }^{87}$

\subsubsection{Procedure for developing customary law}

The community's adherence to customary rules is centred on having consultative meetings to deliberate on matters affecting the community. It is from these meetings that decisions are made and have to be complied with. Therefore, a traditional authority may adopt a system of majority rule in changing its customs and traditions, but at the same time must not ignore the concerns of the minorities. Even if the majority of the community has voted in favour of changing the customs, the courts will remain the independent arbiter of the Constitution. The courts have a duty to protect the rights of the minorities and others who cannot protect their rights adequately through the democratic process. ${ }^{88}$ Therefore, the custom development process should be guided not by what the majority are saying, but by whether or not the decision taken by traditional authorities is in the interests of what is fair and just in terms of the Constitution and the community at large. The Constitutional Court has reiterated the importance of traditional authorities in taking the initiative to bring their customs and traditions in line with the Constitution. Therefore traditional authorities are empowered to change and update their customary law in compliance with the Traditional Leadership and Governance Framework Act ${ }^{39}$ and the Constitution. ${ }^{90}$ Thus, in cases where many customs and traditions in South Africa remain un-codified (non-statutory), ${ }^{91}$ any development in them would be acknowledged if it could be made in writing.

87 Bhe case par 86 (n 28). Shilubana case par 49 (n 9).

88 S v Makwanyane 1995 (3) SA 377 (CC) par 88-89.

89 S 2(3) of the Traditional Leadership and Governance Framework Act (n 69).

90 S 211(2) of the 1996 Constitution.

91 Rautenbach (n 1) 107. 


\section{Conclusion}

Without doubt one is likely to see more women appointed to traditional chieftaincy thrones as a result of the Shilubana judgment. This approach is indeed an achievement for the protection and fulfilment of women rights. The Shilubana judgment builds on the Bhe judgment, in which the court imposed changes to the customary law rules on inheritance, thus bringing them in line with the requirements of gender equality in the Constitution. ${ }^{92}$ The Shilubana judgment ${ }^{93}$ is sensitive to the needs of the community itself and emphasises the importance of respecting decisions made by traditional authorities especially when they are in line with the spirit and purport of the Bill of Rights. ${ }^{94}$ The restoration, especially by traditional authorities, of the chieftaincy thrones to people (women) who were historically barred by custom and tradition indeed brings legal certainty - women are also eligible to occupy positions such as those of traditional leadership. The Constitution should be used as a vehicle for reforming traditional authorities and the latter should be encouraged to take the initiative in developing their own customary law before it becomes necessary for the courts to intervene.

The development of customary law in response to the Shilubana judgment is an essential step in reversing the unfair discrimination that prevented women from succeeding to traditional chieftaincy thrones. ${ }^{95}$ Traditional authorities should not be allowed to reverse the progressive realisation of gender equality by retreating to archaic values. ${ }^{96}$ The Shilubana case makes it clear that, irrespective of gender, the first-born child should succeed his or her father. It should be acknowledged that a second problem may now arise, because only those of royal blood are accepted as rightful heirs to the throne, and women born within the royal bloodline in fact would not bear children from the royal bloodline. Thus, controversy may arise that the authority of the community is being alienated to strangers, or that strangers are being introduced into the

92 Bhe case par 45 ( $\mathrm{n} 28)$.

93 Shilubana case (n 9).

94 De Vos P (n 79).

95 Himonga and Bosch (n 3) 314.

96 Ntshabele (n 46). 
royal blood. The appointment of heirs to the throne must therefore be exercised with due regard to the observance of the customs of the community concerned. ${ }^{97}$

It is important that separate cases be dealt with on their own merits. There is a need for a strong and sustained initiative to educate rural communities so as to make a qualitative improvement in gender relations in the rural areas and to pave the way for more substantive equality in the full range of socio-economic issues. ${ }^{98}$ An essential step in the entrenchment of constitutional democracy in those segments of our society that practice customary law is to encourage traditional authorities to transform themselves voluntarily, taking into account the provisions of the Constitution. Equal citizenship entails being able to take part in the shaping of the society in which an individual or people live. To women it means challenging the spoken and unspoken prejudices that keep them out of public life. ${ }^{99}$ The Shilubana decision has ensured that the appointment of women to traditional chieftaincy thrones will be in accordance with the boni mores test, when seen in the context of the societal conditions and the dynamic nature of particular societal groupings. The decision gives recognition to women as adult human beings who are capable of leading and building their communities as leaders. Traditional authorities that take the initiative in appointing women as traditional leaders should therefore be praised for developing customary law in fulfilment of their duties as enunciated in section 211 of the Constitution. 


\section{Bibliography}

Albertyn and Goldblatt 1998 SAJHR

Albertyn C and Goldblatt B "Facing the challenge of transformation:

difficulties in the development of an indigenous jurisprudence of equality" 1998 South African Journal of Human Rights 248-276

\section{Bennett 1994 SAJHR}

Bennett "The equality clause and customary law" 1994 South African Journal of Human Rights 123-130

Bennett Customary law

Bennett TW Customary Law in South Africa (Juta Cape Town 2004)

\section{Heureux-Dube 1997 SAJHR}

Heureux-Dube CL "Making a difference: the pursuit of equality and a compassionate justice" 1997 South African Journal of Human Rights 335353

Himonga and Bosch 2000 SALJ Himonga $C$ and Bosch $C$ "The application of African customary law under the Constitution of South Africa: problems solved or just beginning?" 2000 South African Law Journal 307-341

Molefe 'Ruling clouds' City Press Molefe R 'Ruling clouds Modjadji's reign' City Press Newspaper 8 June 200811

Molefe 'Judgment' City Press Molefe R 'Judgment gives me the courage to fight on' City Press Newspaper 8 June 200811 
Molefe 'Ruling' City Press

Molefe R 'Ruling on women traditional leader stokes tension' City Press Newspaper 8 June 200811

Ntshabele "Reflections"

Ntshabele D "Reflections about gender equality in the institution of chieftainship" in Foundation of Tertiary Institutions of the Northern Metropolis (FOTIM) International Conference Gender Studies Here and Now 17-19 January 2006 CSIR Convention Centre, Pretoria

Olivier et al Indigenous law

Olivier NJJ et al Indigenous law (Butterworths Durban 1995)

Pieterse 2000 De Jure

Pieterse M "Killing it softly: customary law in the new constitutional order" 2000 De Jure 35-53

Rautenbach 2003 Stell LR

Rautenbach C "Some comments on the status of customary law in relation to the Bill of Rights" 2003 (1) Stellenbosch Law Review 107-114

Rautenbach and Du Plessis 2004 SAJHR

Rautenbach $\mathrm{C}$ and Du Plessis W "Evolution of customary succession laws in South Africa" 2004 South African Journal of Human Rights 1-27

SALC 'Harmonisation'

South African Law Commission 'Harmonisation of the common law and indigenous law: The application of customary law: conflict of personal laws' Issue Paper 4-Project 901996

Schoeman-Malan 2007 PER

Schoeman-Malan MC "Recent development regarding South Africa's common and customary law of succession" 2007 (1) PER Potchefstroom Electronic Law Journal 1-33 
Van Rensburg 2001 Obiter

Van Rensburg AMJ "The judiciary and its constitutional mandates to develop and apply customary law" 2001 Obiter 217-227

\section{Register of legislation}

Constitution of the Republic of South Africa 1996

Constitution of the Republic of South Africa Act 103 of 1993

Constitution of the Republic of South Africa Act 200 of 1993

Promotion of Administrative Justice Act 3 of 2000

Traditional Leadership and Governance Framework Act 41 of 2003

\section{Register of court cases}

Bhe $v$ Magistrate, Khayelitsha (Commission for Gender Equality as Amicus

Curiae); Shibi v Sithole and Others; South African Human Rights

Commission and Another v President of the Republic of South Africa 2004

ZACC 17; 2005 (1) SA 580 (CC); 2005 (1) BCLR 1 (CC)

Carmichele $v$ Minister of Safety and Security and Another (Centre for Applied

Legal Studies Intervening) 2001 ZACC 22; 2001 (4) SA 938 (CC); 2001

(10) BCLR 995 (CC)

Du Plessis and Others v De Klerk and Another 1996 ZACC 10; 1996 (3) SA

850 (CC); 1996 (5) BCLR 658 (CC)

Egan v Canada (AG) 1995 (2) SCR 513 (Canada)

Mabuza v Mbatha 2003 (4) SA 218 (C), 2003 (7) BCLR 743 (C)

Mthembu v Letsela 1997 (2) SA 936 (T); 1998 (2) SA 675; 2000 (3) SA 867

(SCA)

Nwamitwa $v$ Phillia and Others 2005 (3) SA 536 (T)

$R$ v Salituro 19928 CRR (2d) 173

S v Makwanyane 1995 (3) SA 391 (CC)

Shilubana and Others $v$ Nwamitwa (Commission for Gender Equality as Amicus

Curiae) 2007 (2) SA 432 (SCA)

Shilubana and Others v Nwamitwa 2008 (9) BCLR 914 (CC)

Shilubana and Others v Nwamitwa CСТ3/07 
Van Breda and Others v Jacobs and Others 1921 AD 330

\section{Register of internet resources}

BBC News 2008 news.bbc.co.uk

BBC News 2008 Botswana gets first female traditional leader news.bbc.co.uk [accessed on 13 June 2008]

CEDAW 2006 www.un.org/womenwatch/daw/cedaw/states.htm Convention on the Elimination of all Forms of Discrimination against Women 2006 States Parties www.un.org/womenwatch/daw/cedaw/states.htm [accessed on 10 June 2008]

De Vos 2008 constitutionallyspeaking.co.za De Vos P 2008 Victory for woman in developing customary law constitutionallyspeaking.co.za [accessed 20 January 2009]

Gender Links [no date] www.genderlinks.org.za/ Gender Links [no date] Women in South Africa facts and figures www.genderlinks.org.za/docs/gelectionsdocs/WomenInSA.doc [accessed on 16 July 2008]

Mokotjo 2006 www.ufs.ac.za Mokotjo LE 2006 Property grabbing - An experience of women in Africa: A case of customary and civil law in Lesotho Research project submitted in partial fulfilment of the requirement for the Masters in Development Studies degree in the Faculty of Economic and Management Sciences at the University of Free State Bloemfontein www.ufs.ac.za [accessed on 26 May 2009]

SALC 1998 www.saflii.org/ South African Law Commission 1998 Succession to the head of a family www.saflii.org/za/other/zalc/ip/12/12-2.html [accessed on 16 July 2008] 
Tshehla 2005 www.iss.co.za

Tshehla B 2005 Administration of Justice in the traditional court: traditional justice in practice: a Limpopo case study www.iss.co.za [accessed on 16 July 2008]

\section{List of abbreviations}

par paragraph(s)

s $\quad$ section(s)

CEDAW Convention on the Elimination of all Forms of Discrimination against Women

SALC South African Law Commission 